\title{
Las comunidades mudéjares de las diócesis de Osma y Sigüenza a fines de la Edad Media
}

\author{
Enrique Cantera Montenegro *
}

\section{INTRODUCCIÓN}

Los límites geográficos de las diócesis de Osma y Sigüenza en la Baja Edad Media diferían bastante de los actuales. La diócesis de Osma comprendía la práctica totalidad de la actual provincia de Soria, excepto algunas poblaciones del norte, este y sur que cedía, respectivamente, a las diócesis de Calahorra, Tarazona (entre ellas Agreda, a la que sin embargo me referiré en este trabajo por su estrecha conexión con las poblaciones de la diócesis de Osma y por su dependencia de la corona castellana) y Sigüenza; por el contrario, abarcaba algunas poblaciones del sur de la actual provincia de Burgos. El obispado de Sigüenza, por su parte, cedía gran parte de las tierras del sur y oeste de la actual provincia de Guadalajara a la diócesis toledana, en tanto que se extendía por buena parte del sur de la provincia soriana, y comprendía algunas poblaciones del extremo oriental de la provincia de Segovia (Ayllón y Riaza entre ellas).

Estas tierras se definen, ante todo, por su carácter fronterizo con el reino de Aragón, constituyendo Atienza, en la diócesis de Sigüenza, la salida terrestre más importante del reino de Castilla. Por el contrario,

\footnotetext{
* UNED. Dpto. $\mathrm{H}^{\mathrm{a}}{ }^{\mathrm{a}}$ Medieval, $\mathrm{H}^{\text {a }}$ Moderna y C. Historiográficas.
} 
carecen de centros urbanos y económicos comparables a los del norte y centro de Castilla.

Pese a que en esta comarca el fenómeno mudéjar constituye algo complementario, a modo de prolongación del mudejarismo aragonés ${ }^{1}$, están documentadas en ella varias aljamas y morerías, entre las que sin lugar a dudas destaca la aljama de Agreda -posiblemente en relación con el auge comercial y manufacturero que conoció esta población en los dos últimos decenios del siglo $\mathrm{xV}$-, siendo así mismo de destacar las aljamas de Aranda de Duero, Molina de Aragón, Deza, Arcos de Jalón y Medinaceli, que alcanzarían un nivel de tipo medio entre las aljamas de mudéjares de la corona de Castilla.

El origen de la población mudéjar en las diócesis de Osma y Sigüenza puede encontrarse en dos posibles procedencias: 1.) En la permanencia en estas tierras de grupos de musulmanes tras la reconquista cristiana, aunque más tarde algunas morerías evolucionaran en función de motivaciones específicas. Este es el caso de las aljamas y morerías próximas al reino de Aragón. 2.) En la llegada de grupos procedentes del antiguo Reino de Toledo que emigraron hacia el norte tras su conquista por Aifonso $\mathrm{Vl}$, asentándose principalmente en distintas poblaciones del valle del Duero.

Los antiguos fueros locales nos ofrecen algunas noticias sobre los mudéjares, pero apenas sí sirven para aclarar detalles acerca del asentamiento mudéjar en la región.

En el fuero de Medinaceli, otorgado por el rey Alfonso I el Batallador en el año 1124, se establece que «vecino non tenga voz sin non de moro o de judío", lo que supone, en definitiva, que los judíos y los mudéjares no podían actuar en juicio ni por sí mismos ni en representación de otra persona, lo que es un indicativo de una situación jurídica desventajosa con respecto a la población cristiana ${ }^{2}$.

'M. A. Ladero Quesada: «Los mudéjares de Castilla en la Baja Edad Media», en Actas del I Simposio Internacional de Mudejarismo, Madrid-Teruel. CSiC.-Instituto de Estudios Turolenses, 1981, págs. 349-390 (en concreto véase pág. 356).

${ }^{2}$ A. GARCIA ULECIA: «Los factores de diferenciación entre las personas en los Fueros de la Extremadura castellano-aragonesa", en Anales de la Universidad Hispalense, Sevilla 1975, págs. 212-213. 
Así mismo, en las mejoras del fuero de Molina de Aragón introducidas por el cuarto señor de Molina, don Alfonso, hermano de Fernando IV de Castilla, se dice textualmente: "Moro que fuere forro o finare e non oviere fijo o fija, herédelo el Señor de Molina", lo que supone el derecho del señor a heredar al mudéjar que muriera sin descendencia ${ }^{3}$.

Sin embargo, pese a esta escasez de referencias a los mudéjares en los fueros locales de la comarca de estudio, es probable que en ella tuvieran algún reflejo las disposiciones favorables a los mudéjares que se contienen en los fueros otorgados en la primera mitad del siglo XII en localidades navarras y aragonesas próximas, como Tudela, Calatayud y Daroca, con el fin de evitar el éxodo de la población musulmana tras la reconquista cristiana.

\section{DISTRIBUCIÓN GEOGRÁFICA DE LA POBLACIÓN MUDÉJAR}

Las aljamas y morerías de las antiguas diócesis de Osma y Sigüenza presentan una localización geográfica que explica muchos de sus rasgos constitutivos y de sus condicionamientos históricos a lo largo del período bajomedieval.

A grandes rasgos, las aljamas y morerías de las diócesis de Osma y Sigüenza pueden dividirse en tres grupos en función de su localización geográfica:

1. Aljamas y morerías próximas a la frontera aragonesa: constituyen el grupo de morerías más importantes, sin lugar a dudas. A su vez se distribuyen del siguiente modo:

1.1. Valle del río Queiles: aljama de Agreda, sin duda la más importante de toda esta comarca y una de las diez aljamas más voluminosas del reino de Castilla. Se encuentra muy próxima a las comarcas de Borja, Tarazona y Tudela, todas ellas de fuerte presencia mudéjar. En la comarca de Tarazona (valle

${ }^{3}$ M. Sancho IzQuierdo: El Fuero de Molina, Madrid 1916. 
del río Queiles) existían comunidades mudéjares en Tarazona, Santa Cruz del Moncayo, Torrellas, Grisel, Tórtoles, Vierlas, Cunchillas y Novallas; en la comarca de Borja (valle del río Huecha), en Borja, Malejón, Albeta, Burela, Bisimbre, Agón y Fréscano; en la comarca de Tudela (valle del río Ebro), en Tudela, Fontellas, Ribaforada, Cortes, Murchante, Urzarte, Pedriz, Ablitas, Barrillas, Monteagudo, Tulebras, Cascante, Fitero, Cintruénigo, Corella, Cadreita, Valtierra y Arguedas.

1.2. Valle del río Jalón: aljamas de Deza, Arcos de Jalón y Medinaceli, todas ellas de tipo medio en el conjunto de las aljamas castellanas. El valle del Jalón constituyó también una importantísima línea de mudejarismo en el reino de Aragón, destacando las aljamas de Calatayud, Terrer, Ateca, Alhama de Aragón y Ariza, entre otras.

Las relaciones entre las comunidades mudéjares $-\mathrm{y}$ posteriormente moriscas - castellanas y aragonesas del valle del Jalón fueron tradicionalmente muy intensas a lo largo de toda la Baja Edad Media y comienzos de la Edad Moderna ${ }^{4}$.

1.3. Valle del río Gallo: aljama de Molina de Aragón y pequeña morería de Corduente, dependiente de aquélla. No están muy lejos de valle del río Jiloca, que constituyó otra importantísima línea de asentamiento de comunidades mudéjares en el reino de Aragón, destacando entre todas ellas la de Daroca.

2. Aljamas y morerías del Valle del Duero: Entre todas ellas destaca la aljama de Aranda de Duero, de tipo medio, siendo de mucha menor importancia las morerías de Peñaranda de Duero, San Esteban de Gormaz, Berlanga de Duero y Coruña del Conde.

Quizás conviene recordar que el Valle del Duero, y en general la Meseta septentrional, contó con importantes aljamas mudéjares, de carácter eminentemente urbano, como las de Burgos, Palencia, Medina del Campo, Valladolid, Avila, Arévalo, Segovia, Cuéllar y Sepúlveda.

${ }^{4}$ Véase al respecto M. Garcia-Arenal: Inquisición y moriscos. Los procesos del Tribunal de Cuenca, Madrid, Siglo XXI, 1983, 2. ${ }^{a}$ ed., págs. 80-82. 
3. El tercer grupo estaría formado por las pequeñas morerías de Ayllón y Sigüenza, ligeramente desplazadas de las dos áreas geográficas anteriores, aun cuando Ayllón (valle del Riaza) no se encuentra lejos del Valle del Duero, y Sigüenza (valle del Henares) está relativamente próxima a la frontera aragonesa.

Al igual que sucede con las aljamas y morerías navarras, aragonesas y riojanas, que se concentran en las vegas del río Ebro y de sus afluentes (Alhama, Queiles y Huecha las navarras; Oja, Tirón, Najerilla, Cidacos y Alhama las riojanas; Queiles, Huecha, Jalón, Huerva, Jiloca y Aguas Vivas las zaragozanas; Aguas Vivas, Martín, Guadalope y Guadalaviar las turolenses; Isuela, Flumen y Cinca las oscenses) ${ }^{5}$, las aljamas y morerías de la región de estudio se distribuyen a lo largo del curso de los ríos Duero, Arandilla, Queiles, Jalón, Gallo, Riaza y Henares, lo que determinará en buena medida la importancia de la actividad agrícola en la vida económica de estas comunidades.

\section{TRIBUTACIÓN Y DEMOGRAFÍA MUDÉJAR EN LAS DIÓCESIS DE OSMA Y SIGÜENZA}

Como es suficientemente conocido, los mudéjares castellanos, al igual que los judíos, estaban obligados al pago de determinados impuestos especiales directos en virtud del vasallaje especial y de la protección legal que les dispensaba la corona - «cabeza de pecho» y «servicio y medio servicio»-, así como para ayuda para la guerra de Granada — «servicio de los castellanos de oro»-, además de estar obligados, así

${ }^{5}$ Veánse los trabajos de M. Garcia-Arenal y B. Leroy: Moros y judíos en Navarra en la Baja Edad Media, Madrid. Ediciones Hiperión, 1984; E. CANTERA MonTEnEGro: “Los mudéjares en el marco de la sociedad riojana bajomedieval", en Actas de III Simposio Internacional de Mudejarismo, Teruel, Instituto de Estudios Turolenses, 1986, págs. 21 38: J. M. LACARRA DE MIGUEL: “Introducción al estudio de los mudéjares aragoneses", en Actas del I Simposio Internacional de Mudejarismo, Madrid-Teruel. CSIC. Instituto de Estudios Turolenses, 1981. 
mismo, al pago de todos los demás impuestos indirectos comunes a toda la población castellana ${ }^{6}$.

Las cantidades que hubieron de satisfacer las aljamas y morerías de las diócesis de Osma y Sigüenza en concepto de "servicio y medio servicio» en los años 1463, 1464 y 1501 fueron las siguientes ${ }^{7}$ :

\begin{tabular}{|c|c|c|c|}
\hline & 1463 & 1464 & 1501 \\
\hline Aranda de Duero ${ }^{*} \ldots \ldots \ldots \ldots \ldots \ldots \ldots$ & 1.500 & 3.000 & 2.000 \\
\hline Peñaranda de Duero y Coruña del Conde .... & 1.500 & 1.500 & $600^{8}$ \\
\hline San Esteban de Gormaz. & 400 & 400 & 400 \\
\hline Agreda ... & 2.000 & 2.000 & 6.000 \\
\hline Ayllón & 600 & 500 & 1.000 \\
\hline Medinaceli * & 3.000 & 3.000 & - \\
\hline Deza $^{*} \ldots$... & 3.000 & 3.000 & 2.000 \\
\hline Sigüenza ..... & 500 & 900 & - \\
\hline Arcos de Jalón & 3.500 & 3.500 & 1.500 \\
\hline Molina de Aragón & 1.000 & 1.000 & 1.300 \\
\hline Berlanga de Duero... & - & - & 500 \\
\hline
\end{tabular}

6 En ocasiones los reyes cedían parte, o la totalidad, de las cantidades que le debian satisfacer alguna aljama a personalidades a las que se quería recompensar algún servicio a la corona. Así, en los años 1477 y 1478 Lope de Valdivieso, maestresala de la reina Isabel, tenía situados 2.200 maravedies por juro de heredad en la aljama de los mudéjares de Agreda (Archivo General de Simancas -en adelante AGS-, Registro General del Sello -en adelante RGS_, folio 110. Documento de julio de 1479.

7 M. A. LADERO QueSADA: "Los mudéjares de Castilla en la Baja Edad Media", págs. 383-385.

Las cantidades se expresan en maravedies. Con un asterisco se identifican las comu. nidades que constituían aljama.

${ }^{8}$ Sin Coruña del Conde. 
Las cantidades que hubieron de satisfacer en concepto de «servicio de los castellanos de oro" en el período comprendido entre los años 1491 y 1501 son las siguientes ${ }^{9}$ :

1491149514961498149915001501

\begin{tabular}{|c|c|c|c|c|c|c|c|}
\hline Aranda de Duero * ........... & 16.500 & 29 & - & 37 & 40 & 40 & 40 \\
\hline Peñaranda de Duero * $\ldots \ldots \ldots$ & 4.000 & 9 & - & 6 & 6 & 6 & 5 \\
\hline San Esteban de Gormaz * .... & 5.000 & 10 & - & 7 & 7 & 7 & \\
\hline Agreda $^{*} \ldots \ldots \ldots \ldots$ & 70.000 & 122 & 123 & 118 & 120 & 120 & 114 \\
\hline Molina de Aragón * & 20.500 & 45 & 37 & - & 51 & 51 & 40 \\
\hline Deza * & 23.000 & 45 & 37 & - & 43 & 44 & 44 \\
\hline Arcos de Jalón * .... & 12.500 & 20 & 20 & - & 30 & 30 & 30 \\
\hline Berlanga de Duero * .. & 1.000 & 4 & - & - & 4 & 3 & \\
\hline Ayllón * .. & 11.500 & 19 & 15 & - & 22 & 23 & 23 \\
\hline Medinaceli * & 7.500 & 18 & 17 & 一 & 30 & 30 & 30 \\
\hline Corduente. & 1.000 & - & - & - & - & - & \\
\hline
\end{tabular}

Algunos autores han utilizado las listas recaudatorias del «servicio y medio servicio" y del "servicio de los castellanos de oro" para intentar un acercamiento a la demografía judía y mudéjar a fines de la Edad

9 Los datos están tomados de M. A. LADERO QuesADA: «Datos demográficos sobre los musulmanes de Granada y Castilla en el siglo XV», en Anuario de Estudios Medievales, 8, 1972-1973, págs. 481-490.

Las cantidades se expresan en "castellanos de oro" ( 1 "castellano de oro $=485$ maravedies), excepto para el año 1491 que se expresan en maravedíes. 
Media ${ }^{10}$. En este sentido es especialmente interesante el "servicio de los castellanos de oro", consistente en el tributo a que estaban obligados los judíos y mudéjares de la Corona de Castilla como contribución a los gastos de la guerra de Granada, y debido a que estaban exentos de tomar parte en las actividades bélicas. Teniendo en cuenta que en estas listas se anotan las «pechas» a que estaban obligadas las distintas aljamas, así como que en este tributo debían contribuir sólamente los casados, los viudos y viudas, los varones mayores de veinte años y los menores de esta edad emancipados y con hacienda propia ${ }^{11}$ (tradicionalmente con un castellano de oro por "pecha" y con dos castellanos de oro por "pecha" a partír de 1495), puede conocerse el número aproximado de mudéjares vecinos de una población determinada, o de todo el conjunto de la Corona castellana. En definitiva, si el concepto de "pecha» no es igual al de vecindad se le acerca bastante.

En función del número de "pechas" de los mudéjares castellanos entre 1495 y 1501 - 3.600 "pechas» en 1495-, Miguel Angel Ladero evalúa la población mudéjar castellana a fines del siglo XV entre las 17.000 y las 20.000 personas, aplicando un índice de base 5 , es decir calculando cinco personas por cada "pecha» ${ }^{12}$. Utilizando el mismo procedimiento, y tomando como base los datos de 1495, se obtienen los siguientes resultados para las aljamas de las diócesis de Osma y Sigüenza:

${ }^{10}$ Véanse para los judíos los trabajos de M. A. LADERo QueSADA: «Las juderías de Castilla según algunos "servicios" fiscales del siglo XV", Sefarad XXXI, 1971, págs. 249. 264, L. SUÁREZ FERnÁNDEZ: Documentos acerca de la expulsión de los judíos. Valladolid. CSIC, 1964, pág. 56, y Y. BAER: Historia de los Judíos en la España Cristiana, Madrid, Altalena, 1981, 2 vols. (vol. I págs. 153-155, y vol. If pág. 703 , nota 1), y para los mudéjares el trabajo de $\mathrm{M}$. A. LADERO «Datos demográficos sobre los musulmanes de Granada y Castilla en el siglo XV", ya citado anteriormente.

${ }^{11}$ Así se indica textualmente en una ejecutoria que, con fecha de 1 de febrero de 1488 , dirige el Consejo real a las aljamas de mudéjares del obispado de Sigüenza a fin de que hicieran efectivas, en el plazo de veinte días, las sumas correspondientes al "servicio de los castellanos de oro" del año 1488. En dicha ejecutoria se señala también que las sumas fueran adelantadas por los miembros más ricos de la comunidad, y que posteriormente éstos procedieran a efectuar el correspondiente reparto entre la comunidad (AGS, RGS, fol. 200. Documento de diciembre de 1488).

${ }^{12}$ En general se considera que a fines de la Edad Media los matrimonios cristianos y mudéjares contaban, por término medio, con tres hijos, en tanto que los matrimonios judíos, con cuatro. 
Las comunidades mudéjares de Osma y Sigüenza a fines de la Edad Media

Número de Número de "pechas" individuos

Aranda de Duero $\ldots \ldots \ldots \ldots \ldots \ldots \ldots \ldots \ldots \ldots \ldots . \ldots . \ldots . \ldots$

145

Peñaranda de Duero $\ldots \ldots \ldots \ldots \ldots \ldots \ldots \ldots \ldots \ldots . . \ldots$

45

San Estebán de Gormaz $\ldots \ldots \ldots \ldots \ldots \ldots \ldots \ldots \ldots . \ldots$

50

Agreda

122

610

Molina de Aragón

45

225

Deza

Arcos de Jalón

20 100

Berlanga de Duero

4

20

Aylión

Medinaceli

90

TOTAL

323

1.615

Así pues, los mudéjares de las aljamas y morerias de las diócesis de Osma y Sigüenza, con 323 "pechas» en 1495 -que podían equivaler a unas 300 a 350 familias y a una población global que oscilaría entre los 1.500 y los 1.750 individuos - constituirian, aproximadamente, el 8,97 por 100 del total de los mudéjares castellanos, exceptuados los del recién conquistado reino de Granada, lo que es un porcentaje de tipo medio en el conjunto de la Corona castellana, muy lejos del volumen demográfico de otros conjuntos regionales como el Reino de Murcia (674 «pechas"), las tierras de la submeseta norte (diócesis de Burgos, Palencia, Avila y Segovia, con 712 «pechas») o la Mancha (tierras en su mayor parte bajo la jurisdicción de las Ordenes Militares, con 1.026 "pechas»), pero muy similar al de las diócesis de Toledo y Cuenca en su conjunto (317 «pechas») y al de la Andalucía bética (313 «pechas») y bastante superior al de la Extremadura actual (168 «pe- 
chas»). Teniendo en cuenta, además, la extensión geográfica de unos y otros conjuntos regionales, el porcentaje de población mudéjar de las tierras de las diócesis de Osma y Sigüenza en el conjunto de la población mudéjar de la Corona castellana puede considerarse como medioalto.

Pese a que a estas cifras no puede concedérseles un valor sino meramente aproximativo, nunca exacto, considero que no serán muy lejanas a la realidad. Más interesantes son, sin embargo, a la hora de intentar un acercamiento al tema de la evolución poblacional de la minoría mudéjar a fines de la Edad Media. Así, y para el ámbito geográfico concreto de nuestro estudio, de la puesta en comparación de las distintas relaciones impositivas, especialmente de las del "servicio y medio servicio" de mediados del siglo xv y la correspondiente al año 1501 pueden obtenerse algunas interesantes conclusiones:

1. En líneas generales, puede apreciarse un mantenimiento del volumen impositivo correspondiente a las aljamas y morerías de las diócesis de Osma y Sigüenza, lo que, en mi opinión, revela un sostenimiento demográfico desde mediados del siglo $\mathrm{xV}$ hasta los mismos momentos de la expulsión. Incluso en algún caso concreto, como en el de la aljama de Agreda, se observa un muy importante incremento en las cantidades a satisfacer, lo que, sin duda, obedece a un cremiento demográfico (posiblemente con ocasión de la llegada de grupos de mudéjares desde otros núcleos de población de menor importancia).

2. Algunas morerías que figuran en los "repartimientos" de 1463 y 1464 no aparecen en el cle 1501 ni en los "repartimientos" del "servicio de los castellanos de oro" entre 1491 y 1501. Este es el caso de las morerías de Sigüenza y de Coruña del Conde.

El motivo de su desaparición de las listas recaudatorias pudiera obedecer a alguna exención de tipo fiscal o a una reducción -incluso quizás a la desaparición- del volumen demográfico de la población mudéjar en esas localidades. Lo más probable es que se haya producido una combinación de ambos factores.

Pero además de estos tributos a la hacienda real, los mudéjares debían contribuir también en las imposiciones municipales con el resto de la población. 
En este sentido, se conserva una interesante sentencia pronunciada el 19 de febrero de 1485, en los alcázares de la villa de Escalona, por don Diego López Pacheco, duque de Escalona, marqués de Villena y conde de San Esteban de Gormaz, en el pleito que mantenían la villa de San Esteban de Gormaz y los lugares de su tierra acerca de la tributación. La sentencia, muy completa, se refiere en uno de sus apartados al pecho de los judíos y de los mudéjares, respecto al cual el conde determinó que era de pertenencia concejil; además, se establecía que judíos y mudéjares habrían de pechar conjuntamente con los demás vecinos y moradores de la villa en todo aquello que les correspondiera, así como en cualquier otro "repartimiento" que fuera realizado por el concejo. No obstante, el conde ordenaba que una vez cumplida la suma de lo que cupiera satisfacer a judíos y mudéjares no se impusiera a éstos ningún otro "pecho", ni así mismo fueran incluidos en ningún otro reparto tributario ${ }^{13}$.

A fines del siglo $x V$ los mudéjares de Agreda contribuían al erario municipal con 400 maravedies en concepto de "pechos y derramas", en virtud de una sentencia arbitral dada entre el concejo y la aljama, con el acuerdo de ambas partes ${ }^{14}$.

\section{RELACIONES DE CONVIVENCIA ENTRE LAS COMUNIDADES MUDÉJAR Y CRISTIANA}

Resulta ciertamente difícil abordar el estudio de las relaciones mantenidas por mudéjares y cristianos a fines de la Edad Media en las poblaciones de las diócesis de Osma y Sigüenza, debido a la escasez de documentación conservada. No obstante, las noticias que poseemos invitan a pensar en un progresivo distanciamiento entre una y otra comunidades, resultado de la política abiertamente hostil de las autoridades municipales hacia judíos y mudéjares, cuyo arranque en la década de los ochenta de la centuria decimoquinta bien pudiera encontrarse en la orden

\footnotetext{
${ }^{13}$ Archivo Municipal de San Esteban de Gormaz (sin catalogar), papel suelto, quizás procedente del Libro de actas del concejo.

14 AGS, RGS, fols. 169 y 105. Documentos de marzo de 1493 y de septiembre de 1494, respectivamente.
} 
de apartamiento de judíos y mudéjares en barrios aislados, que analizaremos con detalle un poco más adelante.

Las relaciones de la población cristiana con los mudéjares fueron tradicionalmente mejores que con los judíos en la Edad Media hispana, y también fue mejor y más abierta la actitud de las autoridades concejiles hacia la minoría mudéjar que hacia la minoría hebrea, lo que, sin duda, obedece no sólo a su menor importancia numérica sino, principalmente, a su menor relevancia cualitativa en el conjunto de la sociedad, lo que los hacía menos peligrosos a los ojos de la mayoría cristiana.

Pese a que, indudablemente, existen matices diferenciadores entre lo acontecido en unas y otras localidades del área geográfica de nuestro estudio, considero perfectamente legítimo plantear una evolución global del problema, que resulta muy similar a la que puede apreciarse con carácter general para el marco más amplio de la Corona de Castilla.

Del estudio de la documentación que se ha conservado al respecto parece deducirse que las relaciones entre cristianos y mudéjares fueron tradicionalmente buenas en las poblaciones de las diócesis de Osma y Sigüenza, no existiendo constancia documental de ningún asalto cometido contra las morerías ${ }^{15}$. Particularmente significativo es el caso concreto de Molina de Aragón, donde parece que a fines del siglo XV existía una carnicería única para cristianos, judíos y mudéjares, en la que se expendería la carne de los animales sacrificados con arreglo a los ritos y costumbres particulares de cada comunidad. Al menos esto es lo que cabe deducir de la confesión que el día 18 de agosto de 1492 hizo ante el Tribunal de la Inquisición de Sigüenza Aldonza Fernández, vecina de Molina de Aragón: "Yten he comido carne de judíos e moros, porque en la carneçería de los christianos, por mandado de las justiçias, los judíos arrendadores o físicos degollavan carneros, e lo que sobrava compraban todos que se açercavan. E asymismo acahesçía de los moros, que toda

15 Tan sólo se conserva una carta que el 24 de mayo de 1480 dirige el Consejo Real a don Juan de Gamboa, caballerizo mayor, miembro del Consejo Real y alcaide de la villa de Agreda, a fin de que investigue acerca de la queja que, en nombre de la aljama, fue presentada por varios mudéjares vecinos de Agreda sobre cierto robo de dinero que hacía unos días se había cometido contra ellos en la morería (AGS, RGS, fol. 101. Documento de mayo de 1480). La ausencia de cualquier mención a un asalto a la morería nos hace pensar en un simple hecho delicitivo más que en una persecución propiamente dicha. 
la carneçeria era una» ${ }^{16}$. Este dato, en el que, en mi opinión, es particularmente interesante la actitud permisiva de las autoridades concejiles, queda corroborado en la confesión que por las mismas fechas realizó Pedro Bernal, vecino de Molina de Aragón, ante el mismo Tribunal de la Inquisición de Sigüenza: "E otrosy, he comido carne de moros e de judíos, porque públicamente la degollavan judíos e moros en la carneçería de los christianos, e la pesavan a todos, por mandado de la justiçia e regimiento" ${ }^{17}$.

A pesar de ello, es muy probable que se produjeran algunos incidentes aislados que denotan el creciente ánimo de hostilidad hacia la minoría mudéjar en los úitimos decenios del siglo XV.

Así, cuando en el año 1495 fue juzgado por la Inquisición Yuçe de la Vaçia, alfaquí de la villa de Molina de Aragón, acusado de proselitismo religioso entre la población cristiana ${ }^{18}$, éste alegó que no era cierta la acusación, ya que él se había limitado a responder a los insultos que algunos proferían contra Mahoma y su ley, así como a las voces que daban por la ventana de su mezquita mientras él estaba predicando.

Serán las autoridades locales y las jerarquías eclesiásticas diocesanas quienes darán los primeros pasos tendentes a la adopción de medidas restrictivas hacia la población mudéjar, en un esfuerzo por limitar sus posibilidades de actuación socio-profesional, para de este modo forzar su conversión al cristianismo.

En congruencia con las leyes generales dictadas para el conjunto de la Corona castellana, el sínodo provincial celebrado en Aranda de Duero en el año 1473 recuerda la prohibición de que los mudéjares ejerzan sus oficios en los días de fiestas cristianas.

${ }^{16}$ Archivo Histórico Nacional (AHN), Inquisición, legajo 1930, n. ${ }^{\circ}$ 13. E. CANTERA MONTENEGRO: «Solemnidades, ritos y constumbres de los judaizantes de Molina de Aragón a fines de la Edad Media", en Actas del II Congreso Internacional "Encuentro de las Tres Culturas", Toledo 1985, págs. 59-88 (en concreto, págs. 76-77).

17 AHN, Inquisición legajo 1930, n. ${ }^{p}$ 7. E. Cantera Op. cit., pág. 77.

${ }^{18}$ En la formulación de la acusación inquisitorial se dice textualmente: «E otras vezes por mejor atraher a su seta a los christianos los conbidava e rrogava fuesen a oyr sus sermones a la mezquita" (Archivo Diocesano de Cuenca, legajo 19, núm, 344. M. García ARENAL: Inquisición y moriscos. Los procesos del Tribunal de Cuenca, pág. 9 nota 10, y págs. 119-120). 
En esta misma línea se encuentra la política de proselitismo religioso, claramente apreciable a fines del siglo xV en algunas poblaciones castellanas. Así, en los últimos días del año 1499 o en los primeros de 1500, Brayme de Córdoba, en nombre de la aljama de los mudéjares de Aranda de Duero, se queja ante los reyes de que un fraile franciscano obligaba a los mudéjares, incluidos niños y mujeres, a asistir a sus predicaciones en las iglesias de Santa María y de San Francisco, contando para ello con el apoyo del corregidor. El fraile amenazaba con que si no acudían a las mencionadas iglesias él iría a predicar a la morería. El representante de la aljama afirmaba que, debido a que la villa se encontraba poblada mayoritariamente por labradores y gente del común, suponía un gran peligro para los mudéjares salir de la morería y mezclarse con la población cristiana, por lo que muchos mudéjares se habían ido y otros querían irse a lugares de señorío. Así mismo se quejaba de que el corregidor no sólo no hacía nada para solucionar esta situación sino que daba motivo para que algunas personas afirmaran que los mudéjares debían convertirse, voluntaria o involuntariamente, lo que les ocasionaba serios perjuicios. El 27 de febrero de 1500 el Consejo Real se dirige al corregidor de la villa de Aranda de Duero y le ordena que en adelante no se obligue a los mudéjares a asistir a ninguna predicación, y que éstas no se pronuncien en la mezquita ${ }^{19}$.

Unos días más tarde, el 18 de marzo de 1500, el conde de Cabra y otros miembros del Consejo Real se dirigen al corregidor o juez de la residencia de la villa de Aranda y le ordenan que permita a los mudéjares vender libremente sus propiedades. Así mismo se asegura a los compradores de bienes de los mudéjares la plena propiedad de los mismos ${ }^{20}$. Esta autorización respondía a la queja formulada por maestre Abd Allah y maestre Ydan en nombre de la aljama de los mudéjares de dicha población; éstos alegaban que nadie se atrevía a comprar los bienes que los mudéjares querian vender en el arrabal de la villa y en su término, ya que se afirmaba públicamente que los reyes tenían proyectada la expulsión de los mudéjares y que era su intención quedarse con los bienes propiedad de éstos ${ }^{21}$.

${ }_{19}$ AGS, RGS, fol. 52. Documento de febrero de 1500. Transcribe M. LADERO QUESADA: Los mudéjares de Castilla en tiempo de Isabel I, Valladolid. CSIC, 1969, págs. 245-246, documento núm. 97.

20 AGS, RGS, fol. 49. Documento de marzo de 1500. Trans. M. A. LADERO: Los mudéjares de Castilla en tiempo de Isabel l, págs. 251-252, documento núm. 100.

${ }^{21}$ Ya con fecha de 3 de diciembre de 1493 los reyes se habían dirigido a todas las autoridades locales de los reinos y señoríos reales prohibiendo que ninguna persona mani- 
En definitiva, uno y otro documentos nos muestran una situación deteriorada en las relaciones de convivencia entre las comunidades cristiana y mudéjar, en un momento ya próximo a la promulgación del edicto de expulsión de los mudéjares de la Corona de Castilla.

Parecidas situaciones son apreciables en otras poblaciones de nuestra área de estudio. A fines del año 1493 la aljama de los mudéjares de Agreda se queja ante los reyes de que habian sido tomadas las ropas de paño ribeteadas de seda que llevaban algunos mudéjares, bajo el pretexto de que así se ordenaba en las leyes promulgadas en las cortes de Toledo de 1480. Los representantes de la aljama alegaban que las mencionadas leyes se referian a ropas de seda y no a ropas de paño con ribetes de seda, y el Consejo Real ordena al corregidor y a las justicias de la villa que cumplan las leyes sin buscar subterfugios ${ }^{22}$.

En febrero de 1494 el Consejo Real se dirige al corregidor de la villa de Molina de Aragón y le ordena que en adelante no exija a los mudéjares ropa para él y los suyos, y que si alguna les había tomado que se la restituyera ${ }^{23}$. La aljama se había quejado de que el corregidor le exigía la entrega de ropa de dormir para él y los suyos, y si no la entregaban los prendaba y les hacía otros diversos agravios.

El Consejo aplicaba de forma estricta en esta sentencia la pragmática que había promulgado algún tiempo antes, según la cual ningún corregidor podría exigir la entrega de ropas y de posada, excepto de sus «propios".

Al igual que acontece con la población judía en las fechas inmediatas a la promulgación del edicto de expulsión general de 1492, puede apreciarse cómo los mudéjares eran hostigados por las autoridades concejiles, viéndose obligados a acudir con frecuencia a la justicia regia, que en muchas ocasiones sentenciaba en su favor, tratando de poner coto a los abusos cometidos con ellos.

\footnotetext{
festara que la corona tenía intención de expulsar a los mudéjares de los reinos. Las aljamas se habían quejado de que a causa de ello nadie les compraba sus propiedades ni los contrataban para ningún trabajo (AGS, RGS, fol. 16. Documento de diciembre de 1493. M. A. LADERo: Los mudéjares de Castilla en tiempo de Isabel I, págs. 203-204, documento núm. 62). Esta era la reacción lógica ante la reciente expulsión de la población hebrea.

${ }_{22}$ AGS, RGS, fol. 76. Documento de enero de 1494.

23 AGS, RGS, fol. 384. Documento de febrero de 1494.
} 
Uno de los documentos a que hemos hecho mención un poco más arriba nos pone en relación con un tema de gran interés, como es el de los lazos de unión de la población mudéjar con la jurisdicción señorial.

Pese a que no existen datos suficientes que permitan asegurarlo, parece fuera de toda duda que a lo largo del siglo XV los mudéjares del reino de Castilla, al igual que aconteció con la población hebrea, se fueron desplazando gradualmente a poblaciones de señorío, lo que en mi opinión obedece a una doble motivación: por una parte a que los mudéjares confiaban en obtener en lugares de jurisdicción señorial una protección más directa que la que les podían ofrecer los monarcas, en unos momentos que hacian temer la repetición de las persecuciones antijudias de 1391, y que compensaba sobradamente el sometimiento a unas imposiciones más fijas. Por otra parte por el interés manifiesto de determinados linajes nobiliarios en atraer a sus señoríos a grupos de mudéjares, con los que tratarían de potenciar el desarrollo de la agricultura y de determinadas ramas de la actividad artesanal.

En este sentido, la mayor parte de las poblaciones de la diócesis de Osma y Sigüenza que contaron con la presencia de comunidades mudéjares a fines de la Edad Media eran poblaciones de jurisdicción señorial, laica o eclesiástica (Arcos de Jalón, Medinaceli, Molina de Aragón - señorío de la corona-, Ayllón, Deza, Sigüenza). No obstante, hay que tener así mismo en cuenta que la principal aljama de nuestra área de estudio, la de Agreda, corresponde a una población de realengo, en tanto que otra de las más importantes, la de Aranda de Duero, se encontraba en una población que, aunque estrechamente ligada a la Casa de Haro, perteneció generalmente al realengo.

Así, considero que si al documento de referencia no puede concedérsele sino un valor relativo, por cuanto es una noticia única referida a una población concreta - Aranda de Duero-, es en cualquier caso testimonio de una situación que, en mi opinión, debía ser bastante general en la Corona de Castilla en los últimos años del siglo xV (no en vano, la mayor concentración de población mudéjar en la Corona de Castilla se localiza en las tierras de la Mancha, en su mayor parte bajo la jurisdicción de las Ordenes Militares).

En último término, y como es sobradamente conocido, en las Cortes reunidas en el año 1480 en la ciudad de Toledo fue acordado que en un plazo máximo de dos años todos los.judíos y mudéjares que residían en poblaciones del reino de Castilla habrían de ser recluidos en barrios apar- 
tados, denominados «juderías» y «morerías». Esta disposición, que obedece exclusivamente a motivaciones de índole religiosa ${ }^{24}$, es ya un claro exponente de la creciente animadversión hacia las minorías étnico-religiosas, y un precedente, sin duda, del edicto de expulsión que será decretado doce años más tarde para la población hebrea.

Los Reyes Católicos, o el Consejo Real en su nombre, se limitaron a designar oficiales quienes, de acuerdo con las autoridades locales, se encargarian de determinar el sector urbano donde habrían de recluirse judíos y mudéjares. El barrio designado debería rodearse de una cerca, de forma que se garantizara la más absoluta separación entre cristianos y judíos y mudéjares, y habría de reunir las mínimas condiciones imprescindibles para el normal desenvolvimiento de la vida cotidiana de uno y otro grupo social. Este último requisito no siempre se cumplió con exactitud, lo que dio lugar en ocasiones a la queja de judíos y mudéjares, como tendremos seguidamente ocasión de comprobar en el caso concreto de algunas aljamas mudéjares de las diócesis oxoniense y seguntina.

El rigor con el que esta disposición fue llevada a la práctica varió mucho de unas localidades a otras; en general, da la impresión de que se cumplió con mayor rigor en núcleos de población en los que las comunidades judias y mudéjares tenían un cierto peso específico en el conjunto de la población, en tanto que es muy probable que en aquellos otros en los que no pasaban de ser un grupo marginal continuaran residiendo entremezclados con la población cristiana.

Seguidamente procederé a un rápido análisis del proceso de apartamiento de los mudéjares en algunas poblaciones de nuestra área de estudio, así como de las dificultades y conclictos derivados del mismo ${ }^{25}$. Centraré mi atención en los casos concretos de Aranda de Duero y Molina de Aragón, que son las poblaciones de las que he podido localizar documentación al respecto, pues aun cuando es muy probable que el apartamiento de los mudéjares fuera también llevado a cabo en otras

${ }^{24}$ Con ella se quería evitar el posible proselitismo religioso que judios y mudéjares se esforzarían en ejercer entre sus hermanos de raza recientemente convertidos al cristianismo, de quienes se dudaba de la sinceridad de su conversión.

${ }_{25}$ Este tema lo estudio con mayor detenimiento en mi trabajo titulado «El apartamiento de judios y mudéjares de las diócesis de Osma y Sigüenza a fines del siglo Xv', en Anuario de Estudios Medievales, 17 (1987). Estudios dedicados a la memoria del Profesor Emilio Sáez, vol. I, págs. 501-510. 
localidades —por ejemplo en Deza y Arcos de Jalón, donde los mudéjares constituían un grupo especialmente significativo en el conjunto de la población, o en Agreda y Sigüenza, donde a comienzos de la segunda mitad del siglo xv los mudéjares residían en barrios apartados ${ }^{26}$-, lo cierto es que por el momento no dispongo de ninguna noticia que permita asegurar que después de 1480 se llevó a cabo en ellas un apartamiento de la población mudéjar.

El apartamiento de los mudéjares y de los judíos de Aranda de Duero fue realizado a instancias del Consejo Real por Juan Ortega de Carrión, quien fijó el barrio de la morería extramuros de la villa, en una calle del arrabal del Duero ${ }^{27}$.

El apartamiento de las comunidades judía y mudéjar propició enfrentamientos no sólo entre las aljamaś y el concejo sino también, incluso, en el seno de las propias comunidades. Así, a fines del año 1483 algunos mudéjares vecinos de Aranda de Duero se quejaron ante la justicia regia de que algunos mudéjares mantenian la posesión de las fraguas y "asientos» que tenían fuera del recinto de la morería, donde incluso en ocasiones residían, lo que iba en gran perjuicio de los otros mudéjares que ejercian también los oficios de la herrería y de la calderería y que tenían las fraguas dentro de la morería, ya que los cristianos vecinos de la villa y los que desde fuera llegaban a ella en busca de aficiales herreros y caldereros se dirigian siempre a las fraguas de fuera de la morería. Ante ello solicitan que o se obligue a unos a dejar las fraguas, los "asientos" y todas las demás cosas necesarias al oficio de la herrería que poseian fuera de la morería, o que se permita que todos puedan poseerlas igualmente fuera de la morería. La sentencia del Consejo Real, notificada al corregidor y al alcalde de la villa de Aranda de Duero por carta de fecha de 2 de diciembre de 1483, se atiende estrictamente a lo esta-

${ }^{26}$ Al caso de Agreda me referiré más adelante con mayor detalle. Por lo que respecta a Sigüenza, se conserva una interesante noticia en las Actas Capitulares de la Catedral de Sigüenza que confirma la existencia de un barrio mudéjar a mediados del siglo XV. Esta noticia corresponde al día 5 de junio de 1465, y dice así: "Este día los señores estando en su Cabillo ordinario por su portero rematóse la tienda que tenía el moro Hamete en la morería, en que habitava el dicho moro, en el señor Arcediano de Almaçán, por quinientos maravedís por un año» (J. F. YELA UTRILLA: «Documentos para la historia del cabildo seguntino" en Boletín de la Real Academia de la Historia, LXXXII, 1923, pág. 223.

${ }^{27}$ El arrabal del Duero se encuentra situado al sur del núcleo urbano, del que está separado por el río Duero. Este arrabal se conoce todavía en la actualidad como barrio de Allende Duero, estando ubicado en él un polígono industrial separado de la población por la carretera Nacional I, de Madrid a Irún. 
blecido en la ley de apartamiento de judíos y mudéjares de 1480 , de forma idéntica a lo que se hará en cuantas situaciones similares se produzcan. Así, y en virtud de dicha ley, el Consejo Real ordena a las autoridades de Aranda que permitan a los mudéjares la posesión fuera de la morería de fraguas, herramientas y de todas las demás cosas necesarias para el ejercicio del oficio de la herrería, con la única condición de que ni comieran ni durmieran en las fraguas, así como que no trabajaran durante la noche ${ }^{28}$.

Algunos años más tarde la aljama de los mudéjares de Aranda de Duero se quejó nuevamente ante la justicia regia, en esta ocasión con motivo de la actuación del bachiller Juan de Toro, juez pesquisidor en la villa de Aranda de Duero, quien a petición de los vecinos cristianos del arrabal había ordenado cerrar la calle de la morería por ambos extremos, de tal forma que por las puertas no podían entrar carretas ni bestias cargadas. La aljama alegaba que la calle de la morería era calle pública y que, por tanto, debía permanecer abierta para que por ella pudieran entrar y salir libremente los viandantes, así como los productos necesarios para el sostenimiento de la comunidad mudéjar. Por una carta fechada el 19 de marzo de 1486, el Consejo Real ordenaba al bachiller Juan de Toro que en ambos extremos de la calle de la morería se mantuvieran puertas suficientemente grandes como para que a través de ellas pudieran pasar carretas y bestias cargadas ${ }^{29}$. Dos meses más tarde, y a petición nuevamente de la aljama, el Consejo hubo de otorgar una sobrecarta ordenando el cumplimiento de lo dispuesto en dicha carta, pues la aljama se había quejado de que algunas personas habían levantado casas en la proximidad de las puertas de la morería, dificultando el acceso a la misma ${ }^{30}$.

Es probable que algunos mudéjares consiguieran burlar durante algunos años la orden de apartamiento, manteniendo su residencia fuera de la morería. Este es el caso de maestre Amete de Torre quien, según la acusación de Alvaro Daza, escribano del concejo de Aranda, vivía fuera de la morería y poseía también fuera de ella tiendas donde comía y dormía y trabajaba públicamente domingos y días festivos, incumpliendo así de forma manifiesta las leyes de apartamiento. Como veremos más adelante, este Amete de Torre era desde el año 1486 alcalde

\footnotetext{
28 AGS, RGS, fol. 173. Documento de diciembre de 1483.

${ }_{29}$ AGS, RGS, fol. 186. Documento de marzo de 1486.

30 AGS, RGS, fol. 202. Documento de mayo de 1486.
} 
de la aljama mudéjar, por lo que podría sospecharse la existencia de una cierta condescendencia hacia él por parte de las autoridades concejiles. No obstante, y por carta de abril de 1490, el Consejo Real ordenó el estricto cumplimiento de las leyes de apartamiento ${ }^{31}$, aun cuando no existe seguridad de que así se hiciera efectivamente, por cuanto, como tendremos ocasión de comprobar en otro apartado, se trata éste de un personaje que gozó en todo momento del favor regio.

El apartamiento de los mudéjares de Molina de Aragón fue realizado por Hernando de Zayas, quien dejó ordenado que si un día, o por crecimiento vegetativo o por la llegada de mudéjares procedentes de otras poblaciones, aumentaba el número de los residentes en Molina, las autoridades locales deberían proceder al alargamiento de la morería ${ }^{32}$. Muy pronto, a fines del año 1493 o a principios de 1494, y en virtud de esta cláusula, la aljama de los mudéjares de Molina de Aragón solicitó del corregidor de la villa el alargamiento de la morería, ya que, según afirmaba, el espacio de que disponian los mudéjares era totalmente insuficiente para el normal desarrollo de la vida cotidiana. Ante la excusa del corregidor de su incapacidad para realizar este alargamiento sin un mandato especial de los reyes o del Consejo, los mudéjares acuden a la justicia regia, obteniendo una carta del Consejo para el corregidor y el regimiento de la villa a fin de que investigaran si era necesario el referido alargamiento, y si así era les ordenaban que procedieran a su realización ${ }^{33}$.

La importancia de este documento no se limita a que nos informa acerca del apartamiento de la comunidad mudéjar molinesa, sino especialmente a que nos da a conocer que a fines del siglo XV esta comunidad era numerosa, habiendo crecido de forma muy considerable el

\footnotetext{
${ }^{31}$ AGS, RGS, fol. 169. Documento de abril de 1490.

${ }^{32}$ A mediados del siglo XIV la población mudéjar de Molina debía ser bastante escasa, por lo que el rey Pedro IV de Aragón, reino al que por entonces pertenecía Molina, le concedió la facultad de no residir apartada de la población cristiana. Así, del 22 de mayo de 1369 se conserva un muy importante documento otorgado en la villa de San Mateo (en el reino de Valencia) en el que las autoridades de la villa de Molina presentan al rey de Aragón Pedro IV diversas peticiones, entre las que ahora nos interesa la siguiente: «Otrossi que los moros, que son pocos, que sean conceiales e no apartados por aliama. Responde el senyor rey que le paresce que se deve fer segund es acostumbrado, pero plázele que si los moros lo demanden..." (Archivo de la Corona de Aragón, Reg. 917, fols. 104v-107v. F. BAER: Die Juden im Christlichen Spanien, I/1. Aragonem und Navarra. Berlin 1929-1936. Reimp. Gregg International Publishers Limited. England, 1970, págs. 420-435, documento núm. 292).

${ }^{33}$ AGS, RGS, fol. 142. Documento de febrero de 1494.
} 
número de sus integrantes en el arco cronológico que media entre los años 1480 y 1494.

De la información promovida por las autoridades molinesas debió desprenderse la necesidad de proceder al alargamiento de la morería, pues dos meses después, en abril de 1494, el Consejo Real se dirigía nuevamente al corregidor y regimiento de Molina para que se informaran acerca de los posibles inconvenientes que para la villa podrían derivarse del alargamiento de la morería ${ }^{34}$.

Al fin prospera la pretensión de la aljama, y el 9 de octubre de 1494 el Consejo ordena al corregidor que proceda al apartamiento de los mudéjares en lugar conveniente, según se establecía en la ley promulgada en las Cortes de Toledo de 1480, pero sin que ello fuera en perjuicio de los vecinos de la villa. Así mismo se ordena a los mudéjares que en el plazo de tiempo que les fuera señalado se trasladen al nuevo emplazamiento de la morería ${ }^{35}$.

En mi opinión, no es probable que se modificara el emplazamiento de la morería, sino que lo más lógico es que se llevara a cabo un alargamiento de la caile o sector urbano que hasta entonces venían ocupando.

Cuando se iniciaba el pleito al que acabamos de referirmos, la aljama de Molina de Aragón presentó otra queja ante las justicias regias, en relación también con el apartamiento en un barrio aislado. Se quejaba la aljama de que el alguacil y otras justicias de la villa les prohibían trabajar los domingos y días festivos, a pesar de que «las dichas lavores fazen dentro en su morería, donde están apartados, o en sus casas propias». En conformidad con la ley de apartamiento de 1480, el Consejo Real autoriza a los mudéjares a trabajar los domingos y días festivos, siempre que lo hicieran en la morería y dentro de sus casas ${ }^{36}$.

Por el contrario, y pese a la importancia de la comunidad mudéjar de Agreda, no he localizado ninguna noticia acerca de un posible apartamiento de los mudéjares que residían en esta población, quizás porque ya tradicionalmente residían en un barrio propio, separados de cristianos

${ }^{34}$ AGS, RGS, fol. 99. Documento de abril de 1494.

35 AGS. RGS, fol. 205. Documento de octubre de 1494.

${ }^{36}$ AGS, RGS, fol. 440. Documento de febrero de 1494. 
y de judíos. Lo que parece seguro es que a mediados del siglo xv la morería ocupaba en Agreda un importante sector de la fortaleza califal, a juzgar por la carta que el 12 de agosto de 1468 la aljama, el alguacil y los adelantados de la aljama dirigieron el rey Enrique IV a fin de exponerle el mal estado en que se encontraba la fortaleza, y muy en especial la torre del homenaje, «que non tiene menas nin petril e estan caydos dos terminados de la dicha torre, en tal menera, señor, que della non se puede fazer defensyón nin guarda, nin el alcayde della se puede aprovechar ». Por ello, suplicaban los representantes de la comunidad mudéjar al rey que se otorgara y librara la cantidad que se estimara conveniente para proceder a la restauración de la torre y de la fortaleza antes de que se viniera abajo definitivamente ${ }^{37}$. El interés de la aljama no respondía a otro motivo que a que al menos una parte de los miembros de su comunidad residía en el castillo.

Lo mismo cabe deducir de otro documento, con fecha de 21 de marzo de 1493, en el que el Consejo Real se dirige al corregidor de la villa de Agreda solicitando información sobre los motivos que tenía para impedir que don Juan de Gamboa, caballerizo mayor de los Reyes Católicos, quien poseía «la fortaleza e morería de esa dicha villa, que es anexa e pertenesçiente a la fortaleza de esa dicha villa», percibiera un impuesto de castellaje por cada carreta que por allí pasaba ${ }^{38}$.

Por lo visto hasta aquí, parece evidente que el cumplimiento de la ley de apartamiento de 1480 dio lugar a frecuentes $y$, en ocasiones, enconadas disputas entre las autoridades concejiles y los oficiales designados al efecto, por una parte, y las aljamas, por la otra. En todo momento la solución de estos pleitos pasará por la exigencia de un estricto respeto a lo establecido en la ley de apartamiento, y con frecuencia, como hemos tenido ocasión de comprobar, la justicia regia fallará en favor de las aljamas mudéjares.

En definitiva, la solicitud de promulgación de una ley de apartamiento de judíos y mudéjares - que partió de medios eclesiásticos y de los representantes de las ciudades y villas en Cortes- en un indicativo más de la creciente animadversión que a fines del siglo $x \mathrm{~V}$ manifestaban las autoridades concejiles y el pueblo mismo contra las minorías étnico-reli-

37 AHN, Diversos: Concejos y Ciudades, leg. 1, núm. 1.

38 AGS, RGS, fol. 155. Documento de marzo de 1493. 
giosas, y que hacen ya presagiar los edictos de expulsión de 1492 y 1502.

\section{ORGANIZACIÓN INTERNA DE LAS ALJAMAS MUDÉJARES}

Escasas son las noticias que nos permiten profundizar en el conocimiento de la organización interna de las aljamas mudéjares de las diócesis de Osma y Sigüenza. No obstante, las que poseemos considero que son ciertamente interesantes en orden al mejor conocimiento de la figura del «alcalde de los moros".

La mayor parte de las noticias documentales de que disponemos se refieren a la aljama de los mudéjares de Aranda de Duero, y nos permiten un seguimiento bastante completo del tema a lo largo de un decenio: el comprendido entre los años 1486 y 1496. La documentación nos muestra la existencia de fuertes conflictos internos en la aljama mudéjar de Aranda de Duero a fines del siglo XV, conflictos que, sin duda, eran similares a los de otras aljamas y comunidades mudéjares castellanas, y que rompen la idea - hoy día insostenible - de la aljamas como bloques monolíticos. En el caso concreto de la figura del «alcalde de los moros", las noticias relativas a la aljama de Aranda de Duero se enmarcan en un contexto más amplio, común a otras muchas aljamas mudéjares del reino de Castilla, que nos muestra una tendencia a la desaparición a fines del siglo XV de la figura del alcalde propio, sin duda con motivo de los continuos enfrentamientos internos que surgian en las aljamas ante la designación de los alcaldes, pues el cargo suponía, en definitiva, una posibilidad de control social y económico de la aljama.

Como ha estudiado el profesor Torres Fontes ${ }^{39}$, el origen de la institución del "alcalde de los moros" de las aljamas castellanas y aragonesas se encuentra en el "cadí al coda", "cadí de los cadíes" o «cadí de la aljama», título que recibían los jueces de Córdoba en tiempos del Califato. Esta figura es ya reconocida por el rey Alfonso X en el Speculum y en el Código de las Siete Partidas. La documentación conservada

39 J. TORRES FONTES: «El alcalde mayor de las aljamas de moros en Castilla», en Anuario de Historia del Derecho Español, XXXII (1962), págs. 131-182. 
nos permite comprobar cómo con el paso del tiempo las aljamas mudéjares castellanas fueron perdiendo su inicial facultad de libre designación de los «alcaldes de moros", competencia que fue asumida por los monarcas. Así, a lo largo del siglo xv la manifestación más clara del intervencionismo regio en la vida de las comunidades mudéjares se encuentra en la libre y directa designación que en repetidas ocasiones hicieron de "alcaldes mayores de moros» para las aljamas de algunas poblaciones, de comarcas o de señoríos ${ }^{40}$. Uno de los casos más significativos es, probablemente, el de la aljama de Aranda de Duero, que, además, cuenta con una amplia y rica documentación.

El 16 de mayo de 1486 los Reyes Católicos hicieron merced del cargo de "alcalde de los moros" de la aljama de Aranda de Duero a maestre Amete de Torre, herrador de profesión y morador en dicha villa, en la vacante producida en el cargo con motivo del fallecimiento del anterior alcalde, Abad Allah Nuño. El nombramiento de maestre Amete se justifica por los reyes por su "suficiencia y habilidad", así como por los servicios prestados a la aljama, llevando aparejados todos los derechos y salarios propios del oficio de la alcadía, así como las honras, franquezas y exenciones de que gozaron los anteriores alcaldes de la aljama. No obstante, unos días después, y a solicitud de maestre Amete, el Consejo Real otorgó una sobrecarta confirmando el nombramiento, ya que algunos mudéjares no cumplían lo establecido en la carta de nombramiento ${ }^{41}$.

La oposición a maestre Amete, muy fuerte, estaba dirigida por un maestre Yuça, quien aparece citado con mucha frecuencia en la documentación del momento, y cuyo objetivo último parece consistir en la desaparición de la figura del "alcalde de moros", reclamando que fueran los alcaldes ordinarios los encargados de juzgar las causas de los mudéjares. En este sentido, se conserva un documento del año 1488, sin datos de procedencia, en el que, a petición de maestre Yuça, se ordena a los alcalces de Aranda de Duero que guarden las leyes que establecen que los mudéjares pueden demandar y ser demandados ante las justicias regias ${ }^{42}$. Unos años más tarde, el 18 de julio de 1490 , el Consejo Real emplaza a maeste Amete, alcalde perpetuo de la aljama de los mudéjares de Aranda de Duero, a fin de tratar el pleito que mantenía con la

\footnotetext{
40 J. TORRES Fontes, ob. cit., pág. 161.

${ }^{41}$ AGS, RGS, fol. Documento de mayo de 1486.

${ }^{42}$ AGS, RGS, fol. 217. Documento de 1488 (s.m.) (s.d.).
} 
aljama, que reclamaba el derecho a que fuesen los alcaldes ordinarios de la villa los encargados de juzgar las causas civiles y criminales de los mudéjares. En la carta de emplazamiento se señala que la aljama alegaba que el nombramiento de maestre Amete como «alcalde perpetuo de los moros" de Aranda iba contra el tenor de las leyes y ordenanzas del reino de Castilla, y que en otras comunidades mudéjares más numerosas no existía esta figura, y si había existido en el pasado había sido suprimida a causa de los escándalos y muertes que su actuación provocó ${ }^{43}$. Finalizaba la aljama su alegación significando que el privilegio de que gozaba iba más en detrimento de la autoridad real que en provecho de la propia aljama, y que tratándose de una designación perpetua si a unos resultaba favorable a otros "odioso y sospechoso" ${ }^{44}$.

En seguimiento de este pleito, el 27 de agosto de 1490 el Consejo Real comisiona a los Padres Inquisidores de la Villa de Aranda de Duero para que lo examinen y comprueben la veracidad de las argumentaciones empleadas por una y otra parte. En respuesta a la citación del Consejo se presentó Amete de Torre mostrando la carta de nombramiento como alcalde de la aljama, así como un escrito de alegaciones en el que afirmaba usar bien del oficio y no haber cometido ninguna falta por la que debiera ser privado del mismo. Por el contrario, acusaba a los demandantes -entre los que se cita a maestre Abd Allah y a maestre Yuça, «con fasta syete o ocho moros»- de ser «personas escandalosas» ${ }^{45}$.

Las continuas quejas de diversos miembros de la aljama obtuvieron finalmente un éxito parcial, y asi, en el mes de mayo de 1492, el Consejo Real ordena a maeste Amete que tome como «acompañado» suyo a un alcalde ordinario de la villa de Aranda para entender en los pleitos de Abrahén Doñaxonxe, mudéjar vecino de esta población, quien sospechaba de la parcialidad del "alcalcie de los moros», ya que éste permitía que sus parientes la fatigaran a él y a otros pariente suyos ${ }^{46}$. Lo realmente interesante de esta sentencia es que se están poniendo las bases

${ }^{43}$ Casos similares al de Aranda de Duero están constatados documentalmente en las aljamas de Toledo y de Segovia. Así, la aljama de los mudéjares de Toledo renunció a la autoridad de la alcadía mayor, delegando sus funciones en el propio concejo. Por su parte, la aljama de los mudéjares de Segovia rechazó en el año 1480 la autoridad del alcalde mayor nombrado por los Reyes Católicos, J. TORRES FONTES: «El alcalde mayor de las aljamas de moros en Castilla», págs. 155-156 y 160).

44 AGS, RGS, fol, 249. Documento de julio de 1490.

45 AGS, RGS, fol. 193. Documento de agosto de 1490. Existe otra carta igual, probablemente copia, de la misma fecha y con la referencia de AGS, RGS, fol. 61 .

46 AGS, RGS, fol. 302. Documento de mayo de 1492. 
para una futura actuación conjunta de los alcaldes ordinarios de la villa y del «alcalde de los moros», lo que supondrá una desvirtuación de esta figura al perder su tradicional autonomía; así, se ordena que en casos similares al presentado por Abrahén Doñaxonxe actúen conjuntamente los alcaldes ordinarios de la villa y el alcalde de la aljama. Unos años después este carácter ocasional se convierte en definitivo; así, el 15 de julio de 1496, y como consecuencia de las quejas formuladas por diversos miembros de la aljama - Izmael de Barrio, maestre Mahoma de Corral y otros parientes suyos - contra la actuación del "alcalde" de los moros", el Consejo Real acuerda que en adelante el alcalde de la aljama tome siempre por "acompañado" al corregidor de la villa o a su alcalde ${ }^{47}$.

Entretanto se había producido el relevo en el cargo de «alcalde de los moros" de la aljama de Aranda de Duero, por fallecimiento de Amete de Torre, siendo nombrado en su sustitución en febrero de 1494, y de por vida, maestre Yuça ${ }^{48}$. En mi opinión se trata del mismo maestre Yuça que unos años antes encabezaba el movimiento de oposición a maestre Amete de Torre, lo que puede significar un vuelco en las esferas de poder de la aljama. En la carta se ordena a las autoridades de la villa de Aranda que reciban a maestre Yuça como alcalde la aljama, que le guaiden todos los privilegios, honras e inmunidades correspondientes a dicho cargo, y que le paguen el salario a que tenía derecho. Así mismo se ordena a todos los mudéjares que lo reciban como su alcalde y le obedezcan como tal.

Referido así mismo a la aljama de Aranda de Duero, conocemos un interesante pleito en torno a la actuación del alfaquí de la aljama. Así, en el año 1485 Abd Allah de maestre Alida, en nombre y representación de varios mudéjares de Aranda de Duero, se quejó ante las justicias regias de la actuación del alfaquí que desde hacía unos años servía a la aljama, ya que, además de ser muy viejo, no era competente para el desempeño del oficio, pues «non sabe bien los secretos de su ley". Según Abd Allah, en virtud de una tradición de tiempo inmemorial, los mudéjares de Aranda de Duero, con el consentimiento y la concordia de todos los miembros de la aljama, nombraban un alfaquí que había de servirles en todos los asuntos jurídicos de fuero interno. El último nombramiento había recaído

47 AGS, RGS, fol. (sin folio). Documento de julio de 1496. Trans. M. A. LADERO: LoS mudéjares de Castilla en tiempo de Isabel I, pág. 211, documento número 70.

${ }_{48}$ AGS, RGS, fol. 21. Documento de febrero de 1494. 
en una persona que no era competente para el oficio, por lo que habían hecho saber el deseo de la aljama de que lo dejara; pese a ello, sus parientes lo mantenían por la fuerza, por lo que acudieron a la justicia regia. El 13 de septiembre de 1485 el Consejo Real ordena a las justicias de la villa de Aranda que examinen la demanda presentada y resuelvan según fuera de justicia ${ }^{49}$.

Finalmente, tenemos también noticia de algunos enfrentamientos internos en algunas de las comunidades mudéjares de nuestra área de estudio, con motivo de pleitos matrimoniales, que nos aportan algo de luz sobre la vida de dichas comunidades.

El 30 de agosto de 1490 los Reyes Católicos ordenan al corregidor de la villa de Molina de Aragón que examine la demanda interpuesta por maestre Farax, vecino de Molina, contra Alí de Arévalo, vecino de la misma población, por razón de que éste pretendía romper el contrato de desposorio que hacía siete años se había concertado entre su hijo Alí y Zora, hija del demandado, con la finalidad de casar a ésta con otro mudéjar al que ya le había dado palabra de ello. Maestre Farax alegaba que el contrato de desposorio entre Alí y Zora se había realizado legítimamente, con arreglo a la ley musulmana, y que había sido corroborado mediante el intercambio de joyas y con otras ceremonias diversas, por lo que pedía que se tuviera por firme ${ }^{50}$. El interés de este documento, al margen de informarnos parcialmente sobre los contratos de desposorios mudéjares - contratos que se firmaban por los respectivos padres con varios años de antelación a la celebración de la boda, y que normalmente tenían por finalidad sellar algún tipo de pacto entre dos familias-, radica en que, en mi opinión, la circunstancia de que la demanda se remita para su estudio al corregidor de la villa es un claro indicativo de que por esas fechas la aljama de Molina de Aragón no contaba con un «alcalde de los moros", ya que éste sería un asunto propio de este alcalde.

Lo mismo cabe decir con respecto a otro pleito planteado en la villa de Agreda, también por una cuestión de índole matrimonial, aun cuando diferente a la anteriormente referida. El 26 de enero de 1494 el Consejo Real encomienda al corregidor de la villa de Agreda que examine el pleito promovido por Mahoma Lebrero, Hame Lebrero, Mahoma de Huerta y Mahoma el Romo, mudéjares vecinos de Agreda, contra Martín de Cas-

49 AGS, RGS, fol. 130. Documento de septiembre de 1485.

50 AGS, RGS, fol. 149. Documento de agosto de 1492. 
tejón y Martín Gómez, quienes hacía cuatro años, desempeñando el cargo de alcaldes ordinarios de la villa de Agreda, les habian condenado al pago de una multa de ciento treinta reales, después de haberlos tenido presos durante varios días, por unas burlas que habían hecho a unos mudéjares que se casaban. Los demandantes alegaban que todo cuanto habian hecho era que una noche pusieron unas pinturas en las puertas de la casa de los novios, en medio de otras burlas que estaban haciendo en el barrio de la morería, según acostumbran a hacer los musulmanes en las bodas, y que por ello los alcaldes ordinarios promovieron un pleito contra ellos, comprometiendo la causa en manos de unos jueces árbitros, con quienes se repartieron más tarde la multa impuesta ${ }^{51}$. Todo hace pensar que tampoco existía en Agreda un alcalde de la aljama mudéjar.

Por último, algunas noticias nos permiten confirmar el mantenimiento de relaciones amistosas entre mudéjares y miembros de otras comunidades étnico-religiosas de las poblaciones correspondientes, y su participación mutua en festines y en fiestas de carácter religioso. Buen ejemplo de ello es la declaración que realizó ante el Tribunal de la Inquisición de Sigüenza Mari Fernández, mujer de Pedro de Cetina, vecina de Molina de Aragón, acusada de judaizante, quien "comió carne degollada de moros, en especial una espalda, y fue a una boda de moros, y bayló y tomó fruta» ${ }^{52}$.

Aún cuando se carece de documentación suficiente que permita asegurarlo, en mi opinión es muy probable que estas relaciones entre las comunidades judía y mudéjar (o judeoconversa y morisca) no obedezcan exclusivamente a una amistad estrictamente personal, sino quizás a unos lazos de unión más profundos en los que podrían intervenir de forma poderosa el sentimiento de minoría perseguida y un eclecticismo religioso-cultural. Así, sabemos que a fines del siglo xV algunos moriscos vecinos de Molina de Aragón realizaban diversas ceremonias y ritos judíos en compañía de judeoconversos. Buena prueba de ello la tenemos en el proceso inquisitorial promovido contra Diego Fernández, vecino de Molina, en el que Antón García ceclaró que recordaba "commo estando muerto Juan, morisco, fijo de Diego Fernández, morisco defunto, no quiso enterrarle ni consintyó que se enterrase fasta que metió el dicho Diego Fernández, morisco, por su mano un grano de plata al dicho Juan, mo-

51 AGS, RGS, fol. 77. Documento de enero de 1494.

52 AHN, Inquisición leg. 1930. núm. 29. 
risco, su fijo" ${ }^{53}$. El mismo Diego Fernández fue acusado de que, junto con otros conversos, bañó el cadáver de Juan de Zafra según el rito judío ${ }^{54}$.

Es muy probable que este Diego Fernández, morisco, profesara una religión ecléctica, mezcla de cristianismo, islamismo y judaísmo, pero en cualquiera caso considero que es perfectamente lícita la hipótesis del mantenimiento de unas profundas relaciones entre las comunidades judía y mudéjar, y especialmente entre las comunidades judeoconversa y morisca, en algunas poblaciones hispanas a fines del siglo XV. Se trata éste de un tema que, en mi opinión, reviste un gran interés, y en el que habrá que profundizar, pues sin duda aportará datos del máximo interés en orden al mejor conocimiento de la sociedad hispana de fines de la Edad Media y de los primeros tiempos de la Edad Moderna.

\section{ACTIVIDADES SOCIO-PROFESIONALES DE LA POBLACIÓN MUDÉJAR}

Pese a que los datos que poseemos acerca de la dedicación socioprofesional de la población mudéjar en las diócesis de Osma y Sigüenza no son todo lo numerosos que sería de desear, sí son claramente significativos de unas tendencias profesionales que, en definitiva, se asemejan mucho a las que con carácter general presenta la población mudéjar castellana. Estos datos son confirmados con los que se poseen -mucho más numerosos- sobre la población morisca a lo largo del siglo xvl; así, en nóminas de moriscos condenados o reconciliados por la Inquisición y en procesos inquisitoriales seguidos contra moriscos acusados de cumplir ocultamente con la religión musulmana encontramos multitud de noticias sobre moriscos artesanos, entre los que destacan fundamentalmente los dedicados a distintos oficios del sector textil (tejedores de lienzos y bordadores) y metalúrgico (herreros, caldereros, cuchilleros), así como alfareros, cesteros, zapateros y alpargateros, estereros, etc. Así mismo son

${ }^{53}$ AHN, Inquisición leg. 1930, núm. 30. Se trata ésta de una ceremonia típicamente judoespañola; véase al respecto mi trabajo «Solemnidades, ritos y costumbres de los judaizantes de Molina de Aragón a fines de la Edad Media», citado anteriormente.

54 Ibidem. 
numerosos los dedicados a la arriería y trajinería y, en menor medida, a la construcción.

Es muy probable que en la mayor parte de las poblaciones en las que residia una comunidad mudéjar un sector importante de la misma se ocupara en distintas actividades agrícolas, en especial en el cultivo de las huertas que rodeaban el recinto urbano, de forma muy particular en poblaciones ubicadas en el valle de un río, como Aranda de Duero, Arcos de Jalón y Deza. No obstante, son escasísimas las noticias que se han conservado al respecto, lo que tampoco debe llamar excesivamente la atención ya que la agricultura se trata de una actividad que normalmente deja pocos vestigios documentales y que en casi todas las épocas escapa a la curiosidad del historiador contemporáneo, por producirse en los niveles más humildes de la actividad humana.

Más numerosas son las noticias relativas a mudéjares dedicados a distintos oficios artesanales, entre los que sin duda alguna destacan los del sector metalúrgico, en especial herreros y caldereros.

Como hemos tenido ocasión de comprobar en otro apartado, los herreros mudéjares fueron especialmente importantes en Aranda de Duero, localidad en la que en la década de los ochenta de la centuria décimoquinta surgió un interesante pleito entre los herreros y caldereros mudéjares que tenían sus fraguas dentro del recinto de la moreria y los que las tenían fuera, ya que aquéllos se consideraban seriamente perjudicados en sus intereses, por cuanto los cristianos que vivian en Aranda y los que llegaban a ella desde otras poblaciones en busca de útiles de herrería y calderería acudian invariablemente a las fraguas ubicadas fuera de la morería.

Conocemos, así mismo, el nombre de algunos mudéjares herreros, como maestre Ydan de Torres, vecino de Aranda de Duero en el año $1500^{55}$; Carrillo, vecino también de Aranda de Duero en $1493^{56}$; y Braén de Arévalo, vecino de San Esteban de Gormaz en el año 1490. Éste se quejaba de que las autoridades concejiles de Aranda de Duero no le

${ }^{55}$ C. Carrete Parrondo: Fontes ludaeorum Regni Castellae. Il. El Tribunal de la inquisición en el Obispado de Soria (1486-1502), Universidad Pontificia de Salamanca-Universidad de Granada. Salamanca 1985, pág. 157, parágrafo 375.

56 AGS, Patronato Real, Inquisición leg. 28/73, fol. 1.121 r. ${ }^{\circ}$ C. CARRETE, ob. cit., pág. 182, parágrafo 444 . 
permitían la entrada en la villa con motivo de una antigua acusación de la que había sido finalmente absuelto, recibiendo con ello gran agravio y daño ya que necesitaba acudir a la botica pública en ella existente para adquirir productos necesarios para el ejercicio de su oficio, así como debido a que en Aranda se celebraba contratación del oficio de la herrería. Este es un dato más que viene a confirmarnos la importancia de la herrería en Aranda de Duero, actividad en la que los mudéjares debían tener prácticamente el monopolio en esta localidad. Finalmente, el 3 de abril de 1490 el Condestable de Castilla don Pedro Fernández de Velasco y el Consejo Real se dirigen a los alcaldes de la villa de Aranda de Duero y les ordenan que, en adelante, no pongan impedimentos a Braén de Arévalo para entrar y contratar en Aranda ${ }^{57}$.

Algo similar sucedía en Agreda, población donde los mudéjares debieron ostentar también un auténtico monopolio de la herrería. Así, en una relación de moriscos vecinos de esta villa que fueron reconciliados por la Inquisición en el año 1588 figuran 21 herreros de un total de 37 varones documentados ${ }^{58}$.

La alfarería fue otra de las actividades que ocupó a buen número de mudéjares en las poblaciones de nuestra área de estudio. En ocasiones algunos mudéjares participaron, incluso, en trabajos de mucha mayor relevancia que los que podían realizarse en los pequeños talleres o alfares de carácter familiar, donde se procedía a la elaboración de los distintos útiles imprescindibles para la vida doméstica. Este es el caso de Alcallen, vecino de Sigüenza, a quien con fecha de 19 de agosto de 1486 el cabildo seguntino acuerda que se le haga entrega de diez reales "para el cocer de los arcaduces» ${ }^{59}$.

Así mismo, existe constancia documental de algunos mudéjares dedicados al oficio de la carpintería, entre los que pueden ser citados Alí de Córdoba y Barriga, vecinos de Agreda en 1492. Este último se convirtió al cristianismo, trasladándose a vivir a Berlanga de Duero ${ }^{60}$.

${ }_{57}$ AGS, RGS, fol. 130. Documento de abril de 1490.

${ }^{5 B}$ AHN, Inquisición, libro 790 , fols. 90 r. ${ }^{\circ}-99 \mathrm{v} .^{\circ}$.

59 J. F. YeLA UTRILLA: "Documentos para la historia del cabildo seguntino", en Boletín de la Real Academia de la Historia, LXXXII, 1923, págs. 379-380.

El arcaduz es el caño por donde se conduce el agua, por lo que es posible que este Alcallen participara en alguna obra de canalización de aguas.

${ }^{60}$ AGS, Patronato Real, Inquisición, leg. $28 / 73$, fols. 937 r. ${ }^{\circ}-1.121 \mathrm{v} .{ }^{\circ}$ Carlos CARRETE, ob. cit., pág. 159, parágrafo 383 . 
En algunas poblaciones fueron también muy importantes los zapateros mudéjares. Una de estas poblaciones es Agreda, donde a fines del siglo XVl el ejercicio de la zapatería constituía, numéricamente, la segunda de las actividades profesionales ejercidas por los moriscos, inmediatamente detrás de la herrería, teniendo constatados documentalmente en el año 1588 un total de nueve zapateros moriscos ${ }^{61}$.

Teniendo en cuenta el carácter fronterizo de las tierras de las diócesis de Osma y Sigüenza, es muy posible que buen número de mudéjares se dedicaran al oficio de la arriería y de la trajinería, lo que les permitía una gran libertad de movimientos. En este sentido, sabemos con certeza que las relaciones entre las comunidades mudéjares castellanas y aragonesas establecidas en poblaciones situadas a uno y otro lado de la frontera fueron muy intensas a fines del siglo $\mathrm{xV}$, perpertuándose estas relaciones a lo largo del siglo XVI entre las comunidades moriscas descendientes de aquéllas.

Aunque en sentido inverso no poseemos ninguna noticia al respecto, sabemos que en el mes de enero de 1475 la reina Isabel concedió una carta de seguro a varios mudéjares vecinos de Daroca para que pudieran entrar libremente con sus mercancias en el reino de Castilla, sin otro requisito que el de satisfacer los derechos acostumbrados ${ }^{62}$. No obstante, el hecho de que exista amplia constancia documental de moriscos de distintas poblaciones de las diócesis de Osma y Sigüenza dedicados a los oficios de la arriería y de la trajinería nos permite suponer que serian también numerosos los mudéjares que se ocuparían en esta actividad profesional.

En definitiva, y pese a que los datos que poseemos son, ciertamente, muy escasos, pueden apuntarse algunas preferencias profesionales entre los mudéjares de nuestra área de estudio: agricultura, artesanía textil, zapatería, metalurgia y arriería y trajinería.

61 AHN, Inquisición, libro 790 , fols. $90 \mathrm{r}^{\circ}-99 \mathrm{v} .^{\circ}$.

62 AGS, RGS, fol. 51. Documento de enero de 1475. 


\section{EL EDICTO DE EXPULSIÓN GENERAL DE 1502 EN LAS COMUNIDADES MUDÉJARES DE LAS DIÓCESIS DE OSMA Y SIGÜENZA}

Las noticias de que disponemos - en su mayor parte de carácter indirecto - inducen a pensar que la inmensa mayoría, si no la totalidad, de los mudéjares que residian en las poblaciones de las diócesis de Osma y Sigüenza se convirtieron al cristianismo en el año 1502, como consecuencia del edicto que obligaba a los mudéjares del reino de Castilla a optar entre la conversión o el exilio. La conversión al cristianismo les permitía continuar residiendo en sus lugares habituales de residencia y permanecer en la posesión de todos sus bienes y pertenencias.

La confirmación de esta hipótesis la encontramos en el muy elevado número de moriscos que pueden ser constatados a los largo del siglo XVI en aquellas poblaciones de las diócesis oxiniense y seguntina que contaron en la Baja Edad Media con importantes comunidades mudéjares ${ }^{63}$. Se trata de núcleos de población muy próximos al límite del reino de Aragón, en los que la población morisca fue especialmente densa y homogénea, siendo fácilmente constatable el mantenimiento de intensas relaciones, incluso de parentesco, entre familias moriscas que residian en núcleos de población aragoneses (Séstrica, Calanda, Calatayud y Daroca) y castellanos (Deza, Arcos de Jalón, Molina de Aragón y Agreda).

Debido al afán por controlar a los moriscos granadinos deportados del reino de Granada y establecidos en Castilla, se procedió a partir de los años setenta de la centuria décimosexta a la confección de padrones y nóminas de moriscos, entre las que a nosotros nos interesan especialmente los elaborados por el Tribunal del Santo Oficio en los años 1581, 1589 y 1594. A través de ellos puede observarse cómo a fines del siglo XVI eran pocas las localidades de la diócesis seguntina que conocían la presencia de una comunidad morisca, pero las comunidades existentes eran por regla general muy numerosas, de tal modo que Molina de Aragón, Deza y Arcos de Jalón contaban con más de cien moriscos censados. Se trata de población morisca de origen generalmente antiguo, dando la impresión de ser muy escasos los moriscos procedentes del

63 Véase al respecto M. Garcla-AREnAL: Inquisición y moriscos. Los procesos del Tribunal de Cuenca, págs. 7-29. 
reino de Granada. Así pues, es una población bastante homogénea y que procede directamente de las comunidades mudéjares existentes en las mismas localidades hasta la promulgación del edicto de expulsión.

Lo mismo puede decirse con respecto a las comunidades moriscas de la diócesis de Osma, entre las que destacan de forma particular las de Agreda y Aranda de Duero.

Otro hecho que viene a corroborar la importancia de algunas comunidades moriscas en nuestra área de estudio es el elevado número de procesos inquisitoriales seguidos por la Inquisición contra moriscos acusados de perseverar en el seguimiento de la religión musulmana: particularmente numerosos son los procesos seguidos contra moriscos vecinos de Arcos de Jalón (95 procesados a lo largo del siglo XVI) y Deza (93 procesados), que suman la tercera parte de los procesos seguidos contra moriscos en el distrito inquisitorial de Cuenca (diócesis de Cuenca y Sigüenza). Muy de lejos les siguen Molina de Aragón con 15 procesados, y Medinaceli con 6.

Pese a que no se conservan procesos inquisitoriales seguidos contra vecinos de poblaciones de la diócesis de Osma, sí contamos con algunas nóminas de penitenciados por el Santo Oficio, así como también con algunas relaciones de sambenitos de penitenciados, expuestos en las iglesias parroquiales correspondientes ${ }^{64}$. En estas nóminas es bastante elevado el número de moriscos vecinos de Agreda, población que a lo largo del siglo XVI contó también con una importante comunidad morisca. Suficientemente justificativa de cuanto decimos es la relación de moriscos que fueron admitidos a reconciliación en el año 1588 por el licenciado Fernán Cortés, inquisidor del reino de Navarra y de su partido, en la que figuran 75 moriscos vecinos de Agreda ${ }^{65}$.

En el año 1609 están cerisados 14 fuegos moriscos en Aranda de Duero, 24 en Agreda y 18 en Molina de Aragón ${ }^{66}$. En el año 1610, en la relación de moriscos que se registraron en la ciudad de Burgos ante el

${ }^{64}$ Una relación de sambenitos, conservada en el AHN, Inquisición, libro 789 , fols. $244 \mathrm{~V}-$ $247 \mathrm{v}$, ha sido publicada en mi trabajo titulado «Inquisición de Logroño: Sambenitos del siglo XVI’, en Berceo, n. ${ }^{\circ} 103$ (1982), págs. 51-68.

${ }_{65}$ AHN, Inquisición, libro 790, fols. 90r-99v.

${ }_{66}$ Asi se contiene en las respuestas que fueron dirigidas al Consejo de Estado. ${ }_{\$} \mathrm{H}$. LAPEYRE: Géographie de l'Espagne morisque, Paris 1959, págs. 164-165. 
conde de Salazar para salir hacia el reino de Francia, figuran los siguientes ${ }^{67}$ :

Agreda: 19 casas y 96 individuos.

Estado de Medinaceli: 128 casas y 697 individuos.

Aranda de Duero: 3 casas y 12 individuos.

Del mismo año 1610 se conserva una relación elaborada por el conde de Salazar sobre los moriscos que permanecieron en el reino de Castilla tras la expulsión de $1610^{68}$. En ella se contienen las siguientes noticias relativas a nuestra área de estudio:

Aranda de Duero y Sepúlveda: «En este corregimiento y en la villa de Ayllón ay siete casas que todas se an quedado, por aver dado ynformaçiones de buenos cristianos".

Agreda: «En esta villa an quedado diez casas de Moriscos pobres y se a enbiado orden al corregidor las encamine a un lugar más allá de Burgos donde se an de juntar con otros de aquel partido".

Molina de Aragón y Atienza: «Responden deste corregimiento que no ay granadinos ningunos, sino treynta cassas de antiguos».

Estado de Medinaceli: «En este estado no ay granadinos sino de los antiguos treynta y una casa y son tan antiguos que no saven su origen; a los de la villa de Medinaceli se les a dado mandamiento para que se queden por decreto de V. Magd.»

Así pues, en mi opinión, cuanto hasta aquí se ha expuesto creo que justifica plenamente la hipótesis de la conversión al cristianismo de la gran mayoría de los mudéjares que en el año 1502 residían en poblaciones de las diócesis de Osma y Sigüenza.

67 H. LAPEYRE, ob. cit., págs. 198 y 252.

68 AGS, Estado, leg. 235. Henri LAYPEYAE, ob. cit., págs. 254-259. 
No obstante, es muy probable que algunos mudéjares -especialmente los pertenecientes al estrato social más elevado- optaran por el exilio en el año 1502. Ninguna noticia poseemos, sin embargo, al respecto. De unos años antes sí tenemos constancia documental de un mudéjar vecino de Agreda que pasó al reino de Granada, probablemente en el año 1487. Se trata de Mahomad Tural, quien al marchar a Granada dejó sus pertenencias a Ayaya, alfaquí de Molina de Aragón, y a quien reclamaba estos bienes Íñigo de Lariz, como si fueran de pertenencia real ${ }^{69}$.

\section{CONCLUSIONES}

Finalmente, y a modo de resumen de cuanto se ha dicho hasta aquí, pueden apuntarse las siguiente conclusiones:

1. Las aljamas y morerias de las diócesis de Osma y Sigüenza se localizan, preferentemente, en la proximidad de la frontera aragonesa (valles de los ríos Queiles, Jalón y Gallo) y en el valle del río Duero, en líneas de fuerte poblamiento mudéjar, tanto en el reino de Aragón como en la Corona castellana.

2. Pese a la existencia de algunas comunidades mudéjares de cierta importancia (Agreda, Aranda de Duero, Deza, Arcos de Jalón, Molina de Aragón), el mudejarismo constituye en estas tierras un elemento complementario en el conjunto de la sociedad.

A fines del siglo $\mathrm{xV}$ el número de familias mudéjares oscilaría entre las 300 y las 350 -unos 1.500 a 1.750 individuos, aproximadamente-, constituyendo el 8,97 por 100 del total de los mudéjares castellanos, lo que, teniendo en cuenta la extensión geográfica de las dos diócesis, puede considerarse como un porcentaje medio-alto.

3. Si desde el punto de vista cuantitativo la población mudéjar no pasó de constituir sino un sector absolutamente minoritario en el conjunto

69 AGS, RGS, fols. 156, 153 y 359. Documentos de febrero y abril de 1488 y agoosto de 1489 , respectivamente. 
de la población de las diócesis de Osma y Sigüenza, su importancia cualitativa fue mayor, contribuyendo de forma significativa a la promoción y desarrollo de diversas actividades profesionales. En este sentido, es de destacar su papel en el desarrollo de determinadas ramas artesanales, especialmente de la metalurgia, y secundariamente de la artesanía textil y de la zapatería. Así mismo, es digno de significar el impulso que los mudéjares dieron a la agricultura, en particular a la horticultura, y su actividad como arrieros y trajineros.

4. Las relaciones de convivencia entre cristianos y mudéjares fueron tradicionalmente buenas en las poblaciones de las diócesis oxoniense y seguntina a lo largo de toda la Baja Edad Media. Sin embargo, en los últimos decenios del siglo $x V$ es fácilmente perceptible un progresivo distanciamiento entre una y otra comunidades, resultado de la actitud abiertamente hostil de las autoridades locales y de las jerarquías eclesiásticas diocesanas, en un esfuerzo por limitar sus posibilidades de actuación socio-profesional para, de este modo, propiciar su conversión al cristianismo. El agudizamiento de las tensiones en la década de los ochenta se encuentra, sin duda, en estrecha conexión, con la orden de apartamiento de los mudéjares del reino de Castilla en barrios aislados, decretada en las Cortes de Toledo de 1480, y cuya ejecución conocemos en Aranda de Duero y Molina de Aragón.

5. A fines del siglo $x V$ se producen algunos enfrentamientos internos en algunas aljamas de las diócesis de Osma y Sigüenza, siendo de especial significación los que surgen en la aljama de Aranda de Duero en torno a la figura del "alcalde de los moros", y que, en definitiva, contribuyen a desechar la idea - hoy día insostenible - de las aljamas como bloques monolíticos.

6. Por último, la documentación disponible induce a considerar que la inmensa mayoría de los mudéjares que residían en poblaciones de las diócesis de Osma y Sigüenza se convirtieron al cristianismo en 1502, como consecuencia del edicto que obligaba a los mudéjares del reino de Castilla a optar entre la conversión o el exilio. Probablemente fueron muy escasos los que optaron por el exilio, dirigiéndose en este caso hacia las vecinas y florecientes aljamas aragonesas. La confirmación de esta hipótesis se encuentra en las voluminosas comunidades moriscas que a lo largo del siglo XVI pueden constatarse en algunas localidades (Agreda, Deza, Arcos de Jalón), y en las que la presencia de moriscos de origen granadino es mínima. 
